\title{
"Commercial Revolution" of Science: The Complex Reality and Experience of Genetic and Genomic Scientists
}

\author{
ISABELLE GANACHE
}

\begin{abstract}
According to advocates and authors from different disciplines interested in biomedicine, biomedical research in genetics and genomics has the potential to transform medicine, the economy, society, and humanity as a whole. Believing in this potential, biomedical scientists produce knowledge and participate in the decisions concerning the orientation of this research and its applications. Through a qualitative analysis of scientists' practice-related discourse, we identified three main sources of complexity in their involvement in the "commercial revolution" of science. First, scientists insist on the existence of different types of university-industry relationships. Second, they urge that the multiple realities of genetic and genomic research be acknowledged. Third, they present themselves as individuals in a diverse scientific community, each with a unique position in this commercial revolution. This paper draws attention to these complexities because they must be considered when engaging in a study of genetics and genomics advances from a research ethics perspective.
\end{abstract}

\section{Introduction: Impact of genetic and genomic advances and scientists' views}

Genomics is sometimes presented by its advocates as a new paradigm that is transforming biology, medicine, and pharmacology. ${ }^{1,2}$ The economy emerging from the "commercial revolution" of science ${ }^{3}$ is one in which genetics and genomics play an exceptional role, as studies demonstrate. ${ }^{4,5}$ Influencing popular imagination, a powerful vector of social changes, the media presents scientists as manipulating DNA, producing clones or hybrids, etc. ${ }^{6,7}$ In addition, much research addresses the involvement of genetic mechanisms in reproduction or in gene inactivation, stimulation, and replacement. According to visionary scientists and philosophers, this research opens the door for an eventual post-human future, for better ${ }^{8,9}$ or worse. $^{10,11,12}$

Biomedical scientists who produce knowledge in genetics and genomics play an important role in orienting these fields and their applications. A literature review identified the few empirical studies conducted by social scientists that have analysed the experiences, perspectives, views, and opinions of these scientists. These studies are presented below in a summary that groups them by topics investigated.

Surveys of US scientists demonstrated that on the whole, they reject the idea of patenting specific DNA sequences, ${ }^{13}$ are in favour of gene therapy on somatic cells for medical purposes,${ }^{14}$ and approve of general access to genetic tests, prenatal testing, and abortion in case of serious diseases. ${ }^{15}$ Other American studies identify concerns among scientists about the sources of normative research frameworks, ${ }^{16,17,18,19}$ and one UK study shows that many researchers do not follow ethical guidelines. ${ }^{20}$ In the US and Europe, public attention (at times considered beneficial or less beneficial), public ignorance, controversies based on misconceptions or lack of information are also 
subjects of concern for scientists. ${ }^{21,22}$ In the US and the UK, public outreach has been perceived as a means of informing the general public and gaining public confidence ${ }^{23}$ and improving general scientific culture, ${ }^{24}$ and as a moral responsibility for all scientists, ${ }^{25}$ even when it is not supported. ${ }^{26}$ A Quebec study presented reflections on social responsibilities and the limits of science, ${ }^{27}$ while a UK study has identified strategies that help in considering scientists' moral responsibilities: a better use of the scientific method, clarification of their roles, public debate, peer reviews or ethical evaluations, respect for normative frameworks, and personal responsibilities. ${ }^{28}$ Discourse analysis has identified rhetorical strategies used by UK researchers to improve their public image, ${ }^{29}$ to dissociate genetics and eugenics, ${ }^{30}$ and to maintain expertise-associated power. ${ }^{31}$ This research concluded that these strategies can mislead the public and prejudice the scientists themselves $;^{32}$ they are never naïve or inconsequential. ${ }^{33}$ Finally, studies addressing university-industry collaborations and the transformation of the nature of scientific inquiry, ${ }^{34}$ along with their perceived sources and consequences, ${ }^{35}$ addressed sensitive topics like conflict of interest and data withholding ${ }^{36}$ because genetic researchers in the US and Canada often have to deal with these issues. ${ }^{37}$

\section{Table I: Main topics of empirical studies with genetic/genomic scientists}

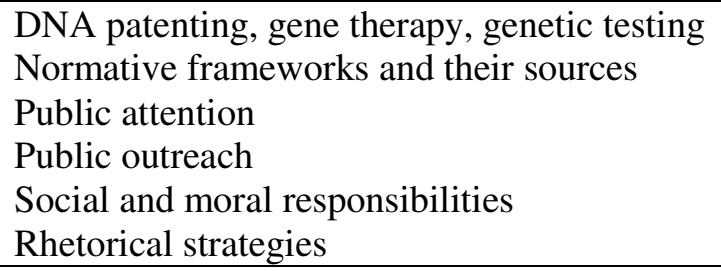

Because of biomedical scientists' importance as knowledge producers in a field that may have significant impacts on our society and even humanity, we believe it is necessary to take into account their views on their actions and their impacts. Based on a literature review of empirical research, we identified different topics investigated with this population: DNA patenting, gene therapy, genetic testing; normative frameworks and their sources; public attention; public outreach; social and moral responsibilities; rhetorical strategies; university-industry collaborations. We discovered that no study concentrated on biomedical scientists' experiences working in genetic or genomic research, as we can do based on our theoretical approach. Even when the topic of university-industry relationship has been investigated in other studies, it did not give the voice to scientists and allow them the opportunity to present their views on their practices and the changes occurring in science.

This paper draws attention to science's "commercial revolution" and how it is experienced by genetic and genomic scientists. The "commercial revolution" of science is presented in the literature as the transformation of science and universities, both of which are taking a commercial or entrepreneurial turn. Different models presented later in this paper have been developed to explain this "commercial revolution" of science: "mode 2 knowledge production", when knowledge is oriented toward applications; "triple helix", where universities, industry, and the State are 
inextricably intertwined in a knowledge-based society; "academic capitalism" or; "enterprise universities."

This "commercial revolution" of science is the object of the central discussion of the paper because it has emerged as a major subject of concern for the scientists who participated in our study and who themselves identified three points of complexity to explore, among others that could have been identified: ${ }^{38}$ 1) the different relationships experienced between universities and industries, 2) the multiple realities designated by the terms genetics and genomics research, and 3) the unique situation of every scientist, in a diverse scientific community, experiencing the "commercial revolution" of science.

\section{Methodology: Shedding light on scientists' views}

Our study aims to shed light on biomedical scientists studying or using genetics and genomics views on their practice and its impacts. It recognises the importance of embedded "implicit normativity" in practices like research. ${ }^{39,40,41}$ These implicit normativities embedded in research represent scientists" "aim for a good life",42 and can be identified in their descriptions of their own experiences, helping their authors give coherence to their actions. ${ }^{43}$

Table II: Methods used to collect scientists' discourses on their experience

\begin{tabular}{|l|l|l|c|}
\cline { 3 - 4 } \multicolumn{2}{|l}{} & Total number of scientists participating the study & $\mathbf{3 2}$ \\
\hline \multirow{3}{*}{ Method Articles } & Number of scientists who wrote articles analysed in this study & 12 \\
\cline { 3 - 4 } & \multirow{3}{*}{ Interviews } & Number of articles analysed & 19 \\
\cline { 3 - 4 } & Number of scientists approached & 71 \\
\cline { 3 - 4 } & Number of scientists interviewed & 22 \\
\cline { 3 - 4 } & Percentage of scientists approached who provided an interview & $31 \%$ \\
\hline
\end{tabular}

The methods used to collect scientists' perspectives. Articles: nineteen articles in the mass media, written by twelve different scientists between December 1991 and May 2005 have been analysed. The "Bibliobranchée" database was used to identify articles written in French and English, addressing genetics, genomics, or research practices. Interviews: seventy-one e-mails were sent to researchers asking for their participation in a one hour semi-directed interview. Twenty-two tape-recorded interviews were conducted between January and December 2005. The qualitative analysis of both articles and interviews used the N'Vivo 2.0 program.

Concerned by the possible implications of advances in genetics and genomics and taking into account scientists' role as producers of knowledge, in this study we used descriptive methodologies to elucidate scientists' views. Here we present data from semi-structured interviews with Quebec biomedical scientists and an analysis of press articles they published themselves (table II). Our interest lay primarily in their 
practice and its impacts. However in the course of the study, the scientists themselves directed our attention to the "commercial revolution" of science and their role in it. As observed by other analyses (see empirical studies addressing university-industry collaborations and the transformation of the nature of scientific inquiry mentioned in the introduction), university-industry relationships are a significant preoccupation for scientists participating in our study. This paper presents various complexities scientists are facing which they specifically identified concerning this "commercial revolution" of science.

\section{Table III: Inclusion Criteria}

Working mainly in the Province of Quebec

Working/Having previously worked as a scientific director

Practising research in biomedical or related sciences

Conducting research on a subject related to human health

Studying genetics or genomics, or using tools from by these fields

Table IV: Participants' characteristics

\begin{tabular}{|c|c|}
\hline Sex & \\
\hline Male & 29 \\
\hline Female & 3 \\
\hline Team Size & \\
\hline$<10$ people & 9 \\
\hline $10-25$ people & 12 \\
\hline$>25$ people & 10 \\
\hline $\mathrm{N} / \mathrm{A}$ & 1 \\
\hline
\end{tabular}

\begin{tabular}{|l|r|}
\hline Experience & \\
\hline$<15$ yrs & 6 \\
\hline $15-25$ yrs & 18 \\
\hline$>25$ years & 8 \\
\hline
\end{tabular}

\begin{tabular}{|l|r|}
\hline Maternal Language & \\
\hline French & 23 \\
\hline English & 4 \\
\hline Other & 5 \\
\hline
\end{tabular}

\begin{tabular}{|c|c|}
\hline Region & \\
\hline Montreal & 21 \\
\hline Quebec City & 7 \\
\hline Sherbrooke & 3 \\
\hline Chicoutimi & 1 \\
\hline Private sector links & 20 \\
\hline Clinical Activities & 8 \\
\hline
\end{tabular}

Quebec biomedical scientists studying genetics or genomics or using the tools offered by these fields (see table III for inclusion criteria) is our population of interest. To identify potential participants, we used lists of research financed by federally and provincially recognised granting agencies, lists of scientists affiliated with Quebec universities, hospitals, and governmental or universities research centres (RC), and private companies. Participants constitute a non-probabilistic sample of this population, thus ensuring that the selection of participants followed an internal diversification using the characteristics presented in table IV. Scientists' research interests were also considered as a source of diversity; we identified those studying different biological processes and diseases, working in different disciplines, and using different approaches and techniques.

\section{Results: Concerns of genetics or genomics scientists participating in science's "commercial revolution"}

The "commercial revolution" of science was identified in our study as being an important preoccupation for participant scientists, which is why the subject is central to our article. This concept has emerged from the discussion with our participants, and is used as a sensitising concept that allows empirical results to shed light on the 
diversity and multiple meaning associated with it, in practice as well as in the literature. ${ }^{44}$ As a group, our participant scientists elucidated different types of relationships that exist between the academic and private research sectors; some of them insisted that these relationships can function very differently. They acknowledged that advances in genetics or genomics were playing an exceptional role in this "commercial revolution," and some of them urged us to consider the multiple realities of this research. Some also demonstrated the diversity and distinctness of their different situations: they are individuals, in their institutions, living the "commercial revolution." These scientists are extremely preoccupied with the three points of complexity that we will develop in this paper.

\section{i) The multiple types of relationships between academic and private research sectors}

Biomedical scientists participating in our study identified different factors they believe are pushing science toward a commercial logic (table V). Scientists consider the costs of research to be very high and ever increasing:

'Material, pharmaceutical and not just pharmaceutical like Fisher, WR and other suppliers... Everything cost so much!'

Scientists also believe that public and private research is under-financed by governments and that it is one factor that pushes academic scientists to associate with private companies. Some of them condemn this situation:

'I decry sometimes that the government does not fund universities that much, they push us more and more into getting money from private sources.'

Others believe in the necessity of transforming research results into applications, with some considering it is the scientist's responsibility to communicate his or her discoveries. As one of our interviewees said:

'I think also it's a responsibility to see whether what he discovers has any chance of being transferred to other laboratories and to, in my case, into hospital, transferred to industry in order to be made into new drug target, to be made into new diagnostic tools.'

Another factor identified by scientists pushing their research toward a commercial logic is the economic interest of new scientific advances like genomic research:
'The economic issues at stake around these discoveries are tremendous...Potential to create new categories of drugs is huge. Moreover, we expect innovative approaches of genomics to allow large scale savings...Genomics raises another economic interest: creation of new diagnostic tests...'

(translation)

Finally, scientists are conscious that research does not evolve independently from its social context, and some of them mentioned the economic logic that governs our society in general, of which research is a part. This opinion, expressed by some participants, illustrates acceptance of economic control over science and scientific 
activities. Other scientists, however, have expressed strong opposition to that economic control, which they deplore regrettably. Different views of research, which underlie different values and ideology, have been illustrated by these opposing opinions.

Table V: Factors identified by biomedical scientists as pushing science toward a commercial logic

\begin{tabular}{|c|}
\hline $\begin{array}{c}\text { Costs associated with research } \\
+ \\
\text { Research under financing } \\
+\end{array}$ \\
Economic interest of genomic research \\
+ \\
Economical logic \\
$=$ \\
Science's commercial revolution
\end{tabular}

The participants' description of the "commercial revolution" of science and factors participating to it.

This is how the participants in our study describe the "commercial revolution" of science. What follows is a discussion on the multiple types of relationships between the academic and private sectors which were put forward by our participating scientists. We believe the multiple opinions and experiences presented illustrate the different meanings accorded by scientists to this transformation of science, multiple views being explained in part by the diversity and individuality of scientists (see section $\mathrm{iii}$ ) below). Before presenting this discussion, we contextualise this "commercial revolution" of science by summarising four models describing the transformation of science. These illustrate the multiple interpretations that can result from these changes.

Within the social sciences and humanities community of researchers and thinkers, it is undisputed that science and the knowledge it produces have been transformed in recent years; universities have evolved accordingly. Regarding economic considerations, many have observed that in the past decades - in the eighties in the US and the nineties in Canada - the universities have adopted an economic mission. ${ }^{45}$ Some authors consider this evolution as the second revolution taking place in the universities; following the first revolution, in which research entered the universities, it is now the time for the "entrepreneurial revolution" revolution." 47

Table VI: Models of the transformation of science and universities: some examples

1) "Mode 2" knowledge production

2) "Triple helix" model

3) "Academic capitalism" theory

4) "Enterprise universities"

Four models of the transformation of science and universities under the "commercial revolution" identified in the social and humanity scientists' and thinkers' community. 
The transformation of science and universities is a subject widely covered in literature and has been reviewed in an article presented by the Finnish sociologist Juha Tuunainen in which he identified four models of transformation ${ }^{48}$ (see table VI). These models differ in their view of this transformation. The first two models are enthusiastic about a dramatic global change in society, including universities, industry, and government. The third and fourth models emphasise moderate, diversified changes in universities, and their controversial effects.

The first model is presented by the English Science Policy expert Michael Gibbons and his colleagues. ${ }^{49,50}$ It argues that research practices associated with "Mode 2" knowledge production, when knowledge is oriented toward applications, are replacing research practices associated with "Mode 1," "traditional" scientific knowledge production. This situation is completely transforming universities, industry, and government, and the relationships between them.

The second model observes a dramatic evolution of science, knowledge, and universities. It is the well-known "triple helix" model presented by the English professor of Management and Innovation, Henry Etzkowitz, and his colleagues. ${ }^{51}$ This model exposes a new configuration in the relationship between universities, industry, and the State, which are inextricably intertwined in a knowledge-based society. The triple helix model demonstrates the arrival of the "entrepreneurial paradigm" in academic science, ${ }^{52}$ the development of "entrepreneurial universities" and "quasifirms" research groups. ${ }^{53}$ According to this model, universities have become central actors in the innovation processes and in social transformation. ${ }^{54}$ For some authors, this model of university-industry-government relations appears in a common format as a worldwide phenomenon ${ }^{55}$ in various countries and transcends national boundaries. ${ }^{56}$

The third model refers to the "academic capitalism" theory. Two American professors of Higher Education Administration, Sheila Slaughter and Larry Leslie, developed this theory to explain how universities present "market and market-like" behaviours, ${ }^{57}$ and to explain the behaviours of actors like scientists and administrators. ${ }^{58}$ These authors look at how "academic capitalism" influences universities as organisations.

Tuunainen's fourth model, the concept of "enterprise universities," is presented by the Australian professors Simon Maginson, who studies education, and Mark Considine, who studies public policy. After empirical research in Australian universities, these professors used this concept to designate the pattern they observed: namely, that since the mid-1980s, universities were becoming more and more like enterprises. These authors find the roots of this change in the history of the universities, and they present the thesis that different universities undergo the change differently.

In the literature on the "commercial revolution" of science, many authors have stated that science has had practical aims throughout its history and that relationships between universities and industry are not new: there have been "important linkages between the history of university science and the corporate laboratories." 59 Some insist that throughout history, research goals have been alternatively fundamental and applied. ${ }^{60}$ Different societies have different needs and objectives that often influence the direction of research. Practical aims for scientific inquiries are found as early as 
the $17^{\text {th }}$ century, when discoveries were often fuelled by an effort to improve industries such as navigation or mining. ${ }^{61}$ The beginning of the academic "entrepreneurial revolution" in the United States can be traced to the $19^{\text {th }}$ century, to the founding of the Massachusetts Institute of Technology (MIT). ${ }^{62}$

Though relationships between universities and industry are not new, many observers believe that the last few decades have brought the commercial revolution of science to a new level. ${ }^{63,64}$ Analysts have attributed this revolution to different causes: 1 ) economic globalisation; ${ }^{65}$ 2) reduction in government funding $;{ }^{66} 3$ ) new government priorities ${ }^{67}$ that see universities as central to innovation and to the knowledge-based economy; ${ }^{68}{ }^{4}$ ) development of agreements encouraging university-industry relationships, ${ }^{69}$ financing of Industries-Liaison Offices ${ }^{70}$ and laws such as the BayhDole Act (1980) in the United Sates ${ }^{71}$ that promote technological transfer from publicfinanced research to the private sector; ${ }^{72} 5$ ) universities' own financial interests. ${ }^{73}$

The four models of science and university transformation presented above are interesting ways of describing the transformations occurring in institutions and science in a global perspective. In the undisputed context of the "commercial revolution," universities and industry do not evolve separately. Also, the links that relate the two research sectors are multiple; scientists in both sectors interact. Our study offers insight on how these transformations are experienced by participant biomedical scientists. First, some participant biomedical scientists observed that current scientific research in both contexts share characteristics that cannot be restricted to one research sector. Some examples: research is generally oriented toward priorities which focus on short- or long-term applicability; research costs money and must be financed somehow; information and results are retained to maintain a competitive edge in both the academic and industry setting; contribution is recognised in terms of money or publications. The scientists who expressed this idea recognise the hybrid nature of academic science and the explicit links between basic and applied research and between the academic and industry visions of research. However, other academic scientists do not recognise science's hybrid nature and try by every means to pursue "pure science" in their university-based laboratory. This illustrates the multiple views or research put forward by different scientists.

Table VII: Types of relationships between academic and private sectors of research as depicted by participant biomedical scientists in this study

Contracts between scientists or organisations

Collaborations between scientists or organisations

Academic research financed by private funding

Consultation and expertise exchange

Commercialisation and patents

Start-up, spin-off, incubation of companies in universities

The transformations occurring within the "commercial revolution" of science and universities as experienced by biomedical scientists who participate in different types of relationships.

Second, participant scientists described their experience of science's "commercial revolution" in terms of different types of relationships (table VII). Some of them insist 
that there are many types of relationships, each being unique in its possible consequences. This constitutes the first point of complexity this paper analyses.

The subject of contractual relationships between scientists and organisations was addressed by our participants. They discussed many different types of contracts, which can be classified in the different categories: ${ }^{74}$ collaborations in which both the university and the industry are equal partners, contracts in which a private firm is the principal and the university provides services, and contracts in which a university is the principal and the firm provides services.

Collaborations, in which both the university and the industry are equal partners, are one type of relationship existing between scientists or between organisations. Collaborations can take different forms, and include the sharing of results, products, techniques, specific expertise, etc. One interviewee explained that good contractual collaborations between university and industry were solidified in a spirit of partnership:
'If you have two groups of scientists, one in academia and one in the pharmaceutical industry working together to solve one problem, both with their strengths, both with their methods and techniques, that's good. And you see that a lot... When you have equals and you have a clear objective, you try to find a solution to a scientific problem...that's totally, totally fair.'

Speaking of contracts in which a firm is the principal and the university provides services in general, one participant believed contracts constituted a clear and fair type of relationship between an academic scientist and a private company:

'you have pure contractual work. So the industry asks you to do something. That's also clean and clear: you can say yes or you can say no but you do a certain task for a certain amount of money, and then the results will totally belong to pharmaceutical industry. I think that's also fair, because then you can decide whether you accept it or not.'

Another participant indicated that he found that contracts in which a firm is the principal and the scientist provides technical services and technological transfer of automated research protocols were leading to boring science: "Scientists don't like that, because those are kind of boring science, generally." This scientist does not consider that kind of contract exciting or likely to lead to new discoveries, which are the basis of his motivation.

Academic research financed by private funding is another type of private-academic contractual relationship, in which a firm is the principal and the university provides services. This has been reported as "occurring more and more often" (translation). Some academic and government scientists have pointed out that finding financing from the private sector was not necessarily an easy task for them.

Another issue associated with this type of relationship is that when financing an academic scientist, a company becomes a partner in his/her research. Many participants underlined that this presented the perverse effect of "giving research 
efforts to companies" (translation) in situations where the research is co-financed by the public and the private sector. The interviewee did not provide any explanation to support his/her position, but this is an opinion shared by some academic scientists from our study as well as others. ${ }^{75}$ The gift of academic research efforts, given to companies, was considered particularly perverse when the financing company was not Canadian. This last idea is the opinion of the interviewee, and it was shared by some other academic scientists though not by the ones who proactively make collaborations with American companies, or by the Canadian government ${ }^{76}$ or Genome Canada, the principal funding agency for genomic research in Canada.

Consultation and exchange of expertise are other kinds of contracts that link universities and firms. For example, some academic participants have reported work as consultants for the private sector, and some scientists from the private sector give information sessions or sit on academic committees. These exchanges of expertise tighten the links between the private and academic sectors of research.

Academic scientists sometimes commercialise their inventions, products, or techniques. Genetic tests are a good example of a product that can be patented and commercialised by academic scientists and their institutions. This way of proceeding was valued by academic scientists with different perspectives, even those who do not want to orient their research toward applications, whether the university contracts a firm to provide commercialisation services or not:

'Patenting...we didn't believe in it, this orientation, okay, but we are not fools either. We said to ourselves, if we find something, we'll have our eyes open and be vigilant'

(translation)

Academic scientists sometimes start companies based on the research results they have obtained in their academic laboratory. The academic scientist then adds the role of entrepreneur to his curricula of teaching and research. In some of these situations, universities or research centers also serve as incubators for the development of such companies.

Appreciation of the different types of relationships between the private and the academic sectors of research leads to a more specific analysis of the situation. Conflicts of values may differ depending on the types of relationships. For example, values such disinterest (implying no financial attachments) or honesty in presentation of results are not equally threatened by the traditional aims of industry; some are in absolute contradiction while others can fit into a commercial vision of research. A conflict of interest is not of the same nature when a partnership links two scientists from both environments compared to when a scientist holds an academic position while chairing a private company. Circulation of information may not be affected equally by a patent on a genetic test and a contract between a big pharmaceutical company and an academic scientist identifying genes that alter individuals' response to a drug. The strategies put in place to regulate these different types of relationships have to take into account the actual situations. 
ii) Of genetics, genomics, and the multiple realities they designate

Some participants believed that the focus on applications and profits was significant in the field of genetics:

'It is more or less evident that in genetics, in biology, today we aim to have concrete results, and we hope that these results will be of the kind that, after, we will be able to fund more projects'

(translation)

The belief that the field of genetics is oriented toward applications is shared by analysts who have identified genetics as an exception in the "commercial revolution." Specifically, physicist and public health policy expert David Blumenthal and his colleagues at Harvard University observed this phenomenon through their quantitative surveys of American academic scientists. ${ }^{77}$ When comparing genetics to other biomedical fields, the team found that there are more companies financing academic research in genetics and that the financing is more generous and extends over a longer period of time. Genetics scientists report more often that they have obtained licences or patents, or that they have started companies linked to their work.

As stressed by participant scientists and analysts, the "commercial revolution" does not affect all research fields equally. ${ }^{78}$ Some scientists who participated in our study extended this observation to the multiple types of research comprised by the terms "genetic research" and "genomic research." These multiple realities designated by the terms "genetics" and "genomics" constitute our second point of complexity.

In identifying the population of scientists who participated in our study, we tried to acknowledge the multiple realities designated. That is why we used the expression "biomedical scientists studying genetics or genomics, or using the tools they offered." First, we used the terms "genetics" and "genomics" because they sometimes designate two very different research fields, even if their actual differences and specificities are often blurred together by lay people as well as by experts (including our participants). Beyond their most basic definitions - study of genes and/ or genomes - these terms are not totally specific and not everyone agrees on their meaning. These words from a participant biomedical scientist illustrate this affirmation:

'...often genomics, many use it to refer to population genetics, but it is more like a mix of different things...I think the definition is so broad.'

(translation)

Second, the labels "genetic" or "genomic" are attached to different kinds of research. Different disciplines are concerned and different approaches, techniques, tools, and methods are included. Supporting this assertion, some participants emphasise the idea that "genomics" is a very large term that includes genetics, proteomics, bioinformatics, population genetics, functional and regulatory genomics, etc. It is perceived as a mix of different approaches: cytogenetics, arrays, sequencing, genotyping, etc. One scientist complained that only one negative connotation is associated with the term by social scientists and ethicists when in fact it designates multiple realities: 
'for me, genomics is an all-encompassing term, and there is only one negative connotation attached to this...this term and I find this deplorable'

(translation)

A third level of complexity is added when genetics or genomics are considered as research fields or tools that can be used to study a particular subject. Some scientists in our study embrace their practice with the aim of forwarding the field of genomics itself: for instance, they develop both techniques at the edge of scientific knowledge and statistical or informatics tools necessary to manage the data produced. Other scientists are interested in using genetic and genomic tools to generate knowledge on diseases like breast cancer:

'Genomics as such, it's a research tool...In itself, it is not an end, it's...it's a mean to reach identification.'

(translation)

Another layer of complexity develops when the research is applied to subjects like monogenic diseases, polygenic diseases, individual responses to drugs, gene modifications, mechanisms implicated in cloning, or population genetics, which represent activities very different from each other.

The later development illustrates the multifaceted or generic nature of the terms "genomics" and "genetics". This begs the question of what such all-embracing terms really mean for scientists and how effectively they use them. Are they only buzzwords used by scientists to fit strategically their research interest into funding agencies or companies orientation or to get social support, as denounced in the literature ${ }^{79}$ and implied by the following quotation of one of our participant scientist?

'...my scientific interest, which is sort of what drives me, is based on my research in [specific research field]...So I want to keep doing that. I don't want to change'

Or do they designate new realities needing new terminologies and potentially leading to new scientific paradigms? Proponents of the two discourses fiercely defend their opinions, and the reality probably exists somewhere between these two extremes.

To conclude and link this section with the key theme of our article, namely "the commercial revolution of science", we want to stress that the potential impact of the results obtained and the forms of knowledge produced in different research situations are not comparable. In respect to commercialisation, the results do not hold the same degree of applicability; their potential markets and commercial interests are completely different. This illustrates that there are many different types of research and potential for commercialisation in one relatively small and well-defined research field.

\section{iii) Diversity of individual scientists in a scientific community}

Our study allowed us to appreciate the individuality of every participant scientist, and therefore the associated diversity of particular situations found in the research 
practices of the scientific community. Scientists are the individuals who live the "commercial revolution," and they present themselves as a diverse community. This constitutes another complexity to consider.

The life contexts of scientists influence their research practices. For example, the culture of origin and of the region where they practise research may have a decisive influence on their vision of commercialisation or profit making. In the same way, the culture of their main workplace - university, research centre, hospital, private company - has to be considered. For example, a clinician and researcher working in a hospital and its research centre may have a different experience of the reality in which his or her research can be applied from the experience of a basic scientist who works in an environment centered on the advancement of knowledge. These elements of life context interact and influence the vision of specific scientists and their research practices. The scientific community shares some beliefs and views; however, the particular situations of individual scientists make them different from one another and bring diversity to the views presented by the community. This is why sometimes - and we saw it repeatedly during our study - the scientists' vision does not precisely align with their employer's vision. In such a situation, the scientists focused on their fundamental interest when employers pushed them toward development of applications: it creates conflicts of engagement. This assertion from one of our participants is an illustration of such a conflict of engagement:

'...my scientific interest, which is sort of what drives me, is based on my research in [specific research field]...So I want to keep doing that. I don't want to change. And if somebody says, well you'll have to be doing something that's practical, I will try and say here's what is practical in what I want to be doing.'

As identified in a study on the use of the term "basic research" by scientists, ${ }^{80,81}$ intentions (curiosity, social benefits, etc.) partly delimit scientists' vision of research and therefore, its possible applicability. However, in order to respond to employers' demands or to secure funding, scientists may present their work with a different emphasis on its possible application. This is one situation in which scientists' discourses may blur the distinction between basic and applied research, without changing their initial intention. This strategy, as expressed in the last quotation, may be used in order to preserve the scientist's autonomy and to keep a distance from application.

We can also add that many scientists accumulate professional attachments, which might be with clinicians and researchers appointed to a university, chairs of companies and university professors. These multiple roles may expose a scientist to different visions of research that may create tensions and lead to conflicts of values or interests. The numerous combinations of professional attachments lead to a diversity of personal situations that must be acutely understood.

Different scientific disciplines have different cultures and potential for the application of research. Genetic and genomic research is often interdisciplinary and illustrates the diversity of expertise needed to embrace projects in new scientific advances: engineers and computer scientists meet physicists, biochemists, molecular biologists, etc. Objects of study chosen by scientists also vary in their potential for application. 
For example, biomedical researchers focus their research on human health, which is itself a step toward the application of research. Other factors also contribute to scientists" views of the "commercial revolution" that they are experiencing and their role in it. The context of their specific research team influences the sum of money they need to operate, for example, and their previous experience, along with other factors, influences the potential to obtain funding from different sources.

Scientists who experience the "commercial revolution" of science and its impacts are individuals. One consequence of the revolution is the transformation of the scientist's role. Expertise in more than one field is necessary to operate at a time when relationships between universities, industries and government are tighter. Riccardo Viale, an Italian researcher in public policy discusses the birth of a new type of scientist, "the entrepreneurial scientist", who is able to "interface basic knowledge with the innovation goal". ${ }^{82}$ Because of their diversity of backgrounds and experiences, not all scientists experience the evolution of their role to the same extent; some of them enthusiastically embrace this entrepreneurial role while others are reluctant to enter the "commercial revolution." Comprised in their own life history, scientists' views of research are influenced by different factors. How these factors influence scientists' willingness to develop applications and how scientists experience the "commercial revolution" of science have implications for the way future research is carried out and therefore for the future of science itself.

\section{Discussion: studying the "commercial revolution" of science from a research ethics perspective}

Scientific advances in biomedicine that studies or uses genetics and genomics in the context of the "commercial revolution" of science constitute an inescapable subject of concern which is extensively discussed in the social science and humanities literature. Many authors have identified the controversial effects of the "commercial revolution" of science. Case studies have shed light on the different problems created by university and industry's increasing and changing relationships-harassment of scientists, conflicts of interests, failures to protect human subjects, lawsuits over results publication, publication bias, diminished integrity and research productivity, diminished public confidence and free circulation of information, disputes over intellectual property, etc. ${ }^{83,84,85,86,87}$ Problems have even been associated more specifically with the practice of research in the field of genetics: one study confirmed that American genetics researchers, more than researchers in other fields, were retaining information (not publishing data, not discussing new results with colleagues, etc.) and that it affected their scientific activity in terms of productivity and exchanges. These cases are sometimes considered illustrations of what is called a "culture conflict" 88 arising between academic research and private sector values. Different values are said to be specific academic ideals - openness, objectivity, academic freedom, scepticism, preservation and dissemination of knowledge, etc. ${ }^{89}$ These values are transmitted from generation to generation during the scientists' education, and we believe they constitute scientific norms, their adherence making the scientists members of the scientific community. Market-driven production, profit orientation, and utilitarianism are traditionally associated with industry. ${ }^{90}$ In practice, these norms are ideals and universities also have interests and work in a context that directs their knowledge production. ${ }^{91}$ However, we agree with authors who claim that 
the clash of values in increasing or intertwined relationships could compromise traditional academic norms as well as industry's mission. ${ }^{92}$ Related to conflicts of values, the issue of conflicts of interests (COI) has attracted a great deal of attention in the context of the "commercial revolution" of science. Authors have presented case studies (8), definitions and categorisations of the concept. ${ }^{93}$ Analysts, including governments, funding agencies, institutions, professional associations, and scientific journals, have presented strategies to respond to COIs. ${ }^{94}$ An academic team of social scientists has presented a code of conduct suggesting the disclosure of COIs, the implementation of nationwide standards and guidelines, hearing processes, certification, surtax on university-industry contracts, ombudsperson, etc. ${ }^{95}$

These problems arising in the context of the "commercial revolution" of science raise various questions. How can universities protect their specific culture? ${ }^{96}$ How can we address conflicts created by the tension, conflicts which are sometimes considered creative ${ }^{97}$

We believe that current research ethics, which have been built and are still articulated around principles, norms and application rules aim to protect research subjects, are not well adapted to new knowledge development like genetics and genomics research in the context of the "commercial revolution" of science. Codes of conduct and guidelines constitute steps in the ethical conduct research, but they present limits when confronted to particular situations. As we demonstrated, the actual practice of research in the field of genetics and genomics and in the context of the "commercial revolution" of science presents a complexity that cannot be addressed by principles and rule applications. Starting from this observation, we plead for a broadening of research ethics that would be interested in practices, implicit normativities, and the views they imply. In our view, research ethics should provide the foundation to address the following questions. What is good research? What type of research should be valued? What kind of knowledge do we want to produce? With what aim? Moreover, the practice of research ethics should allocate considerable efforts to the formation, sensitisation and development of scientific integrity by the actors themselves, who would become reflective about their own practice.

\section{Conclusion}

This article takes into account that, in practice, the "commercial revolution" of science is occurring in many different ways and that the actual situations of the scientists who live these transformations present multiple element of complexity. An important point of this article is to warn analysts not to over-generalise when they address issues emerging from this "commercial revolution". Development of principles, norms, codes of ethics or guidelines to regulate relationships between university and industry constitute a step toward ethical conduct of research. However, when judging problematic situations or in applying general rules of regulation to specific cases, the complexity of concrete situations must always be considered. Through interviews with scientists and consideration of the literature, our article highlights some complexities to consider when studying genetics- and genomicsrelated scientific advances in the context of science's "commercial revolution" from a research ethics perspective. Specifically, we have addressed the following points: i) the multiplicity and uniqueness of university-industry relationships; ii) the multiple 
realities of research designated by the terms "genetics" and "genomics;" iii) the individuality of each scientist and diversity of the scientific community facing the "commercial revolution."

Our discussion merely opens the door for the identification of other complexities and points to the pursuit of work and reflection on how universal principles and rules can be developed and applied to concrete situations. Development of dialogue between scientists from the social sciences and humanities and actors related to their object of study - such as biomedical scientists - is a necessary step toward a sophisticated and nuanced understanding of our current and future situation.

\section{Acknowledgements}

We thank the Groupe de recherche en bioéthique and Genetics and Society Project team members from the Universite de Montreal for their support and comments. We also thank A. Saginur for linguistic corrections. A special thank to B.M. Knoppers and $\mathrm{H}$. Doucet for their guidance and support. This study was supported by a doctorate grant from Fonds québécois de la recherche sur la nature et les technologies, a travel scholarship from the International Institute of Research in Ethics and Biomedicine and a grant from Genome Quebec.

${ }^{1}$ A.E. Guttmacher and F.S. Collins. Genomic Medicine - a Primer. New England Journal of Medicine 2002; 347(19): 1512-1520.

${ }^{2}$ A.E. Guttmacher and F.S. Collins. Welcome to the Genomic Era. New England Journal of Medicine 2003; 349(10): 996-998.

${ }^{3}$ A. Schafer. Biomedical Conflicts of Interest: A Defence of the Sequestration Thesis-Learning from the Cases of Nancy Olivieri and David Healy. Journal of Medical Ethics 2004; 30, 1: 8-24.

${ }^{4}$ D. Blumenthal, N. Causino and E.G. Campbell. Academic-Industry Research Relationships in Genetics: A Field Apart. Nat. Genet. 1997; 16(1): 104-108.

${ }^{5}$ D. Blumenthal, E.G. Campbell, M. Gokhale, R. Yucel, B. Clarridge, S. Hilgartner and N.A.

Holtzman. Data Withholding in Genetics and the Other Life Sciences: Prevalences and Predictors. Academic Medicine 2006; 81(2): 137-145.

${ }^{6}$ D. Nelkin. Molecular Metaphors: The Gene in Popular Discourse. Nature Review Genetics 2001; 2(7): 555-559.

${ }^{7}$ D. Ducharme. 2003. Débat Sur La Génétique Humaine Au Québec: Représentations Et Imaginaires Sociaux. Montréal. Hurtubise HMH: 286.

${ }^{8}$ A. Woolfson. 2005. Genetics: The Future of Life College of Medecine, Heath Park Campus, Cardiff. Cardiff University.

${ }^{9}$ D. Kevles. 1992. Out of Eugenics: The Historical Politics of the Human Genome. In The Code of Codes. L. Hood and D. Kevles, eds. Harvard. Harvard University Press: 18.

${ }^{10}$ F. Fukuyama. 2002. Our Posthuman Future: Consequences of the Biotechnology Revolution. New York. Farrar, Straus and Giroux: 256.

${ }^{11}$ J. Habermas. 2003. The Future of Human Nature. Malden. Polity Press: 136.

12 J. Derrida. 1990. The Aforementing So-Called Human Genome. In Negotiations: Interventions and Interviews, 1971-2001. E. Rottenberg, ed. Stanford. Stanford University Press: 199-214.

${ }^{13}$ I. Rabino. How Human Geneticists in Us View Commercialization of the Human Genome Project. Nature Genetics 2001; 29(1): 15-16.

${ }^{14}$ I. Rabino. Gene Therapy: Ethical Issues. Theorethical Medicine and Bioethics 2003; 24(1): 31-58.

${ }^{15}$ I. Rabino. Genetic Testing and Its Implications: Human Genetics Researchers Grapple with Ethical Issues. Science, Technology and Human Values 2003; 28(2): 365-402.

${ }^{16}$ I. Rabino. Ethical Debates in Genetic Engineering: U.S. Scientists' Attitudes on Patenting, GermLine Research, Food Labeling, and Agri-Biotech Issues. Politics Life Sciences 1998; 17(2): 147-163. 
${ }^{17}$ I. Rabino. What U.S. Researchers Think of Regulations and Regulators: If Regulators Contain Their Political Excesses and Become More Effective, DNA Researchers Will Give Them Guarded Approval. Bio/technology 1996; 14(2): 147-150.

${ }^{18}$ I. Rabino. German Genetic Engineering Scientists and the German Public: Complementary

Perceptions in a Changing European Context. Public Understanding of Science 1992; 3(4): 365-384.

${ }^{19}$ D.J. Mathews, A. Kalfoglou and K. Hudson. Geneticists' Views on Science Policy Formation and Public Outreach. American Journal of Medical Genetics 2005; 137(2): 161-169.

${ }^{20}$ N.J. Goulding, H.C. Waddell and L. Doyal. Adherence to Published Ethical Guidelines by the UK Genetics Research Community. Nature Genetics 2003; 34(2): 117-119.

${ }^{21}$ Rabino, op. cit. note 17.

${ }^{22}$ I. Rabino. The Impact of Activist Pressures on Recombinant DNA Research. Science Technology and Human Values 1991; 16(1): 70-87.

${ }^{23}$ Ibid.

${ }^{24}$ Rabino, op. cit. note 15.

${ }^{25}$ H. Middleton-Price. 1997. The Role of Genetics Professionals in Public Debate - Summary of Survey Results. Available at:

http://www.bshg.org.uk/documents/other_docs/BSHG\%20survey\%20results\%20HMP.doc.

${ }^{26}$ Matthews et al, op. cit. note 19.

${ }^{27}$ Y. Boisvert, J. Monzée and M.-F. Gagnier. 2004. Bio-Ingénierie, Éthique Et Société: De La

Responsabilité À La Responsabilisation Des Chercheurs Et Des Entreprises Privées, Laboratoire D'éthique Publique Enap: Chaire Fernand-Dumont (Inrs). Montréal: 197.

${ }^{28}$ B. Nicholas. Molecular Geneticists and Moral Responsibility: "Maybe If We Were Working on the Atom Bomb I Would Have a Different Argument." Science and Engineering Ethics 1999; 5(4): 515 530.

${ }^{29}$ D. Nelkin. Promotional Metaphors and Their Popular Appeal Public Understanding of Science 1994; 3(1): 25-31.

${ }^{30}$ A. Kerr, S. Cunningham-Burley and A. Amos. Eugenics and the New Genetics in Britain: Examining Contemporary Professionals' Accounts. Science, Technology and Human Values 1998; 23(2): 175-198.

${ }^{31}$ A. Kerr, S. Cunningham-Burley and A. Amos. The New Genetics: Professionals' Discursive Boundaries. The Sociological Review 1997; 45(2): 279-303.

${ }^{32}$ Nelkin, op. cit. note 29

${ }^{33}$ Nelkin, op. cit. note 6.

${ }^{34}$ R. Dalpé, L. Bouchard and D. Ducharme. Scientific, Medical and Industrial Issues in Breast and Ovarian Cancer Genes Research. IEEE International Symposium on Technology and Society, 2000: 91-99.

${ }^{35}$ I. Rabino. Societal and Commercial Issues Affecting the Future of Biotechnology in the United States: A Survey of Researchers' Perceptions. Naturwissenschaften 1998; 85(3): 109-116.

${ }^{36}$ E.G. Campbell, B.R. Clarridge, M. Gokhale, L. Birenbaum, S. Hilgartner, N.A. Holtzman and D. Blumenthal. Data Withholding in Academic Genetics: Evidence from a National Survey. JAMA 2002; 287(4): 473-480.

${ }^{37}$ Blumenthal et al, op. cit. notes $4 \& 5$.

${ }^{38}$ D.L. Kleinman. Untangling Context: Understanding a University Laboratory in the Commercial World. Science, Technology, and Human Values 1998; 3(3): 285-314.

${ }^{39}$ H.A. ten Have and A. Lelie. Medical Ethics Research between Theory and Practice. Theor. Med. Bioeth. 1998; 19(3): 263-276.

${ }^{40}$ A. Molewijk, A.M. Stiggelbout, W. Otten, H.M. Dupuis and J. Kievit. Implicit Normativity in Evidence-Based Medicine: A Plea for Integrated Empirical Ethics Research. Health Care Analysis 2003; 11(1): 69-92.

${ }^{41}$ L.v.d. Scheer and G. Widdershoven. Integrated Empirical Ethics: Loss of Normativity? Medicine, health care and philosophy 2004; 7(1): 71-79.

${ }^{42}$ P. Ricœur. 1990. Le Soi Et La Visée Éthique. In Soi-Même Comme Un Autre. P. Ricœur. Paris. Éditions du Seuil: 199-236.

${ }^{43}$ P. Ricœur. 1990. Le Soi Et L'identité Narrative. In Soi-Même Comme Un Autre. P. Ricœur. Paris. Éditions du Seuil: 167-198.

${ }^{44}$ H. Blumer. What Is Wrong with Social Theory? American Sociological Review 1954; 19(1): 7.

${ }^{45}$ D. Fisher and J. Atkinson-Grosjean. Brokers on the Boundary: Academy-Industry Liaison in Canadian Universities. Higher Education 2002; 44: 449-467. 
${ }^{46}$ H. Etzkowitz. Research Groups as 'Quasi-Firms': The Invention of the Entrepreneurial University. Research Policy 2003; 32: 109-121.

${ }^{47}$ Schafer, op. cit. note 3.

${ }^{48}$ J. Tuunainen. Hybrid Practices? Contributions to the Debate on the Mutation of Science and University. Higher Education 2005; 50(2): 275-298.

${ }^{49}$ M. Gibbons, C. Limoges, H. Nowotny, S. Schwartzman, P. Scott and M. Trow. 1994. The New Production of Knowledge: The Dynamics of Science and Research in Contemporary Societies. Londres. Sage.

${ }^{50}$ M. Gibbons. 2003. Globalisation and the Preservation of University Values. Available at www.bth.se/exr/hss03.nsf/(WebFiles)/E5366FF501835566C1256D4300338EB4/

${ }^{51}$ H. Etzkowitz and L. Leydesdorff. The Dynamics of Innovation: From National Systems and "Mode 2"' to a Triple Helix of University-Industry-Government Relations. Research Policy 2000; 29: 109123.

${ }^{52}$ H. Etzkowitz, A. Webster, C. Gebhardt and B.R.C. Terra. The Future of the University and the University of the Future: Evolution of Ivory Tower to Entrepreneurial Paradigm. Research Policy 2000; 29: 313-330.

${ }^{53}$ Etzkowitz and Leydesdorff, op. cit. note 51.

${ }^{54}$ R. Viale and H. Etzkowitz. 2005. Third Academic Revolution: Polyvalent Knowledge; The "DNA" Of the Triple Helix. Turin, Italie.

${ }^{55}$ Etzkowitz et al, op. cit. note 52.

${ }^{56}$ Viale and Etzkowitz, op. cit. note 54.

${ }^{57}$ S. Slaughter and L.L. Leslie. 1997. Academic Capitalism: Politics, Policies, and the Entrepreneurial University. Baltimore. The Johns Hopkins University Press: 276.

${ }^{58}$ S. Slaughter and L.L. Leslie. Expanding and Elaborating the Concept of Academic Capitalism. Organization overviews 2001; 8(2): 154-161.

${ }^{59}$ M.A. Dennis. Accounting for Research: New Histories of Corporate Laboratories and the Social History of American Science. Social studies of science 1987; 17(3): 510.

${ }^{60}$ B. Godin. Writing Performative History: The "New" New Atlantis? Social studies of science 1998; 23(3): 465-483.

${ }^{61}$ Tuunainen, op. cit. note 48; Etzkowitz and Leydesdorff, op. cit. note 51.

${ }^{62}$ Etzkowitz, op. cit. note 46.

${ }^{63}$ Ibid; Fisher and Atkinson-Grosjean, op. cit. note 45; Tuunainen, op. cit. note 48.

${ }^{64}$ D.B. Resnik and A.E. Shamoo. Conflict of Interest and the University. Accountability in Research 2002; 9(1): 45-64.

${ }^{65}$ Tuunainen, op. cit. note 48; Slaughter and Leslie, op. cit. note 57.

${ }^{66}$ Slaughter and Leslie, op. cit. note 57.

${ }^{67}$ Tuunainen, op. cit. note 48.

${ }^{68}$ Etzkowitz and Leydesdorff, op. cit. note 51.

${ }^{69}$ Resnik and Shamoo, op. cit. note 64.

${ }^{70}$ Fisher and Atkinson-Grosjean, op. cit. note 45.

${ }^{71}$ US/Governement. 1980. Bayh-Dole Act - Patent and Trademark Law Amendment Act.

${ }^{72}$ Resnik and Shamoo, op. cit. note 64.

${ }^{73}$ Etzkowitz and Leydesdorff, op. cit. note 51.

${ }^{74}$ J. Poyago-Theotoky, J. Beath and D.S. Siegel. Universities and Fundamental Research: Reflections on the Growth of University-Industry Partnerships. Oxford Review of Economic Policy 2002; 18(1): $10-21$.

${ }^{75}$ D. Rahm. Academic Perceptions of University-Firm Technology Transfer. Policy Studies Journal 1994; 22(2): 267-278.

${ }^{76}$ S. Bagchi-Sen, L. Hall and L. Petryshyn. A Study of University-Industry Linkages in the Biotechnology Industry: Perspectives from Canada. International Journal of Biotechnology 2001; 3(34): $390-410$

${ }^{77}$ Blumenthal et al, op. cit. notes 4 \& 5 .

${ }^{78}$ Ibid; Tuunainen, op. cit. note 48; Gibbons et al, op. cit. note 49; Slaughter and Leslie, op. cit. note 57.

${ }^{79}$ J.A. Lee. What Was Genomics? Lancet Oncology 2003; 4(9): 584.

${ }^{80}$ J. Calvert. The Idea Of "Basic Research" In Language and Practice. Minerva 2004; 42: 251-268. 
${ }^{81}$ J. Calvert. What's Special About Basic Research? Science, Technology and Human Values 2006; 31(2): 199-220.

${ }^{82}$ Viale and Etzkowitz, op. cit. note 54.

${ }^{83}$ Schafer, op. cit. note 3.

${ }^{84}$ J. Thomson, P. Baird and J. Downie. 2001. Report of the Committee of Inquiry on the Case Involving Dr. Nancy Olivieri, the Hospital for Sick Children, the University of Toronto, and Apotex Inc. - the Summary. Ottawa. Association canadienne des professeures et professeurs d'université: 46.

${ }^{85}$ D. Blumenthal, N. Causino, E.G. Campbell and K.S. Louis. Relationships between Academic Institutions and Industry in the Life Sciences - an Industry Survey. New England Journal of Medicine 1996; 334(6): 368-373.

${ }^{86}$ B. Rappert and A. Webster. Regimes of Ordering: The Commercialization of Interllectual Property in Industrial-Academic Collaborations. Technology Analysis and Strategy Managment 1997; 9(2): 115130.

${ }^{87}$ S. Lewis, P. Baird, R.G. Evans, W.A. Ghali, C.J. Wright, E. Gibson and F. Baylis. Dancing with the Porcupine: Rules for Governing the University-Industry Relationship. Canadian medical association journal $2001 ; 165(6)$ : 783-785.

${ }^{88}$ Fisher and Atkinson-Grosjean, op. cit. note 45.

${ }^{89}$ Schafer, op. cit. note 3; Resnik and Shamoo, op. cit. note 6; S.M. Natale and A.F. Libertella. Education-Business Partnership: Shifting Sands in the University and Corporate Community. The Journal of Value Inquiry 1998; 32: 257-268.

${ }^{90}$ Natale and Libertella, op. cit. note 89.

${ }^{91}$ B. Williams-Jones. Knowledge Commons or Economic Engine - What's a University For? Journal of Medical Ethics 2005; 31(5): 249-250.

${ }^{92}$ Resnik and Shamoo, op. cit. note 64; Natale and Libertella, op. cit. note 89.

${ }^{93}$ D. B. Resnik. Conflicts of Interest in Science. Perspectives on Science 1998; 381-408; Etzkowitz, op. cit. note 45; Resnik and Shamoo, op. cit. note 64.

${ }^{94}$ Ezkowitz, op. cit. note 46; Resnik and Shamoo, op. cit. note 64; Resnik, op. cit. note 93.

${ }^{95}$ Lewis et al, op. cit. 87.

${ }^{96}$ Ibid.

${ }^{97}$ Etzkowitz and Leydesdorff, op. cit. note 51. 